\title{
The donor of carbon monoxide (CORM-2) affects the level of serum immunoglobulins and the state of the bone marrow during the immune response in mice
}

\author{
S. P. Beschasnyi (D)*A-F, O. M. Hasiuk (DB-E \\ Kherson State University, Ukraine
}

A - research concept and design; B - collection and/or assembly of data; C - data analysis and interpretation; D - writing the article;

$\mathrm{E}$ - critical revision of the article; $\mathrm{F}$ - final approval of the article

Toxic carbon monoxide in small concentrations has pro-apoptotic, anti-allergic, vasodilator effects, and stimulates angiogenesis. The problem with the therapeutic use of low doses of carbon monoxide is that it is difficult to dose. To control the amount and gradual release of carbon monoxide, non-toxic preparation is used - $\mathrm{CO}$ donor based on carbonyl compound of ruthenium (CORM-2).

The aim - is to identify the effect of CORM-2 on the level of immunoglobulins in the blood serum and bone marrow of mice under conditions of inducing an immune response.

Materials and methods. 3 groups of 15 white laboratory mice each were formed. Induction of the immune response was due to the intraperitoneal administration of xenogenic red blood cells. The first experimental group on the first day of immunization received CORM-2 (20 mg/kg), group No. 2 - on the $5^{\text {th }}$ day after immunization (period of the productive phase). The control group consisted of immunized animals that did not receive CORM-2. The amount of $\lg A$, $\operatorname{lgM}$, and $\lg G$ in blood serum was determined by ELISA on the $2^{\text {nd }}$ and $6^{\text {th }}$ day after immunization. At the end of the experiment, bone marrow cell populations were counted.

Results. After the injection of CORM-2 during the induction phase of the immune response, it inhibits the production of immunoglobulins. In comparison with the control, the level of $\operatorname{lgA}$ and $\lg \mathrm{G}$ is reduced, but the amount of IgM remains unchanged. In the bone marrow, the number of monocytes, erythroblasts, and normoblasts, as well as lymphoblasts and plasma cells, increased. At the same time, the number of myeloblasts, myelocytes, basophilic normoblasts, and megakaryocytes decreased. The use of CORM-2 during the productive phase caused a decrease in the level of $\operatorname{lgM}$ and $\operatorname{lgG}$ with a simultaneous increase in the level of IgA. The number of neutrophils, eosinophils, monocytes, polychromophilic and oxyphilic normoblasts, lymphocytes, and plasma cells in the bone marrow increased. However, the number of myeloblasts, promyelocytes, myelocytes, metamyelocytes, basophilic normoblasts, and megakaryocytes decreased.

Conclusions. The impact of the CORM-2 on the inductive phase of the immune response leads to inhibition of the production of immunoglobulins. The injection of CORM-2 during the productive phase of the immune response decreased the level of $\operatorname{lgM}$ and $\operatorname{lgG}$, but at the same time, an increase in the level of IgA was observed. After the injection of CORM-2, in the bone marrow, the number of monocytes, lymphocytes, and plasma cells increased. The results indicate that CORM-2 is able to modulate the immune response.

Key words: gas transmitter, carbon monoxide, CORM-2, humoral immune response.

Current issues in pharmacy and medicine: science and practice 2020; 13 (3), 415-420

Донор монооксиду вуглецю (CORM-2) впливає на рівень імуноглобулінів сироватки крові та стан кісткового мозку в умовах імунної відповіді в мишей

\section{С. П. Бесчасний, О. М. Гасюк}

Токсичний монооксид вуглецю в незначних концентраціях характеризується проапоптичною, протиалергійною дією, має вазодилататорний вплив, стимулює ангіогенез. Проблема його терапевтичного застосування полягає у складності точного дозування. Для контролю кількості та поступового вивільнення монооксиду карбону застосовують нетоксичний препарат - донор СО на основі карбонільної сполуки рутенію (CORM-2).

Мета роботи - виявити вплив CORM-2 на рівень імуноглобулінів сироватки крові та кісткового мозку мишей в умовах індукції імунної відповіді.

Матеріали та методи. Сформували 3 групи по 15 білих лабораторних мишей: дві експериментальні й контрольна. Індукцію імунної відповіді спричиняли шляхом внутрішньоочеревинного уведення ксеногенних еритроцитів. Перша експе-

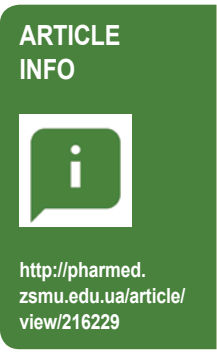

UDC 591.111.1:546.262.3-31:57.08 DOI: $10.14739 / 2409-2932.2020 .3 .216229$

Current issues in pharmacy and medicine: science and practice 2020; 13 (3), 415-420

Key words: gas transmitter, carbon monoxide, CORM-2, humoral immune response.

*E-mail: beschasnyis@gmail.com

Received: 14.07.2020 // Revised: 10.09.2020 // Accepted: 15.09.2020 
риментальна група в перший день імунізації отримала CORM-2 (20 мг/кг), група № 2 - на 5 день після імунізації (період продуктивної фази). Контрольна група - імунізовані миші, які не отримували CORM-2. Визначали кількість $\lg$, IgM, IgG у сироватці крові методом ІФА аналізу на 2 і 6 дні після імунізації. Наприкінці експерименту підраховували популяції клітин кісткового мозку.

Результати. Введення CORM-2 в індукційну фазу імунної відповіді стримує продукцію імуноглобулінів. Порівнюючи з контролем, рівень IgA та IgG знижений, але кількість IgM незмінна. У кістковому мозку збільшилася кількість моноцитів, еритробластів і нормобластів, а також лімфобластів і плазматичних клітин. Одночасно знизилася кількість мієлобластів, мієлоцитів, базофрільних нормобластів, мегакаріоцитів. Уведення CORM-2 в період продуктивної фази спричиняло зниження рівня $\operatorname{lgM}$ та IgG з одночасним підвищенням рівня IgA. Кількість нейтрофілів, еозинофілів, моноцитів, поліхромнофрільних та оксифрільних нормобластів, лімфоцитів і плазматичних клітин у кістковому мозку збільшилася. Кількість мієлобластів, промієлоцитів, мієлоцитів, метамієлоцитів, базофрільних нормобластів і мегакаріоцитів зменшилася.

Висновки. CORM-2 в індукційну фразу імунної відповіді спричиняє пригнічення продукції імуноглобулінів. Уведення CORM-2 в період продуктивної фази імунної відповіді знижує рівень $\operatorname{lgM}$ та $\operatorname{lgG}$, але одночасно спостерігали підвищення рівня IgA. Після застосування CORM-2 у кістковому мозку збільшується кількість моноцитів, лімфоцитів, плазматичних клітин. Результати, що отримали, вказують: CORM-2 здатен модулювати імунну відповідь.

Ключові слова: газотрансміттер, монооксид вуглецю, CORM-2, імунна відповідь.

Актуальні питання фрармацевтичної і медичної науки та практики. 2020. Т. 13, № 3(34). С. 415-420

\section{Донор монооксида углерода (CORM-2) влияет на уровень сывороточных иммуноглобулинов} и состояние костного мозга при иммунном ответе у мышей

\section{С. П. Бесчасный, Е. Н. Гасюк}

Токсический монооксид углерода в незначительных количествах обладает проапоптическим, противоаллергическим действием, имеет вазодилататорное влияние, стимулирует ангиогенез. Проблема его терапевтического использования заключается в сложности точной дозировки. Для контроля количества и постепенного высвобождения монооксида углерода используют нетоксический препарат - донор СО на основе карбонильного соединения рутения (CORM-2).

Цель работы - установить влияние CORM-2 на уровень иммуноглобулинов сыворотки крови и костного мозга мышей в условиях индукции иммунного ответа.

Материалы и методы. Сформированы 3 группы по 15 белых лабораторных мышей. Индукция иммунного ответа получена путем внутрибрюшинного введения ксеногенных эритроцитов. Первая экспериментальная группа в первый день иммунизации получила CORM-2 (20 мг/кг), группа № 2 - на 5 день после иммунизации (период продуктивной фразы). Контрольная группа - иммунизированные мыши, которые не получали CORM-2. Определяли количество $\lg A$, $\lg$ М и $\lg$ в сыворотке крови методом ИФА анализа на 2 и 6 дни после иммунизации. В конце эксперимента подсчитывали популяции клеток костного мозга.

Результаты. Введение CORM-2 в индукционную фазу иммунного ответа сдерживает продукцию иммуноглобулинов. В сравнении с контролем, уровень IgA и IgG снижен, но количество IgM неизменно. В костном мозге увеличилось количество моноцитов, эритробластов и нормобластов, а также лимфобластов и плазматических клеток. Одновременно снизилось количество миелобластов, миелоцитов, базофильных нормобластов и мегакариоцитов. Введение CORM-2 в период продуктивной фразы обусловливал снижение уровня IgM и IgG с одновременным повышением уровня IgA. Количество нейтрофилов, эозинофилов, моноцитов, полихроматофильных и оксифильных нормобластов, лимфоцитов и плазматических клеток в костном мозге увеличилось. Количество миелобластов, промиелоцитов, миелоцитов, метамиелоцитов, базофильных нормобластов и мегакариоцитов уменьшилось.

Выводы. Введение CORM-2 в период продуктивной фразы иммунного ответа снизило уровень IgM и IgG, но одновременно обуславливает повышение уровня IgA. После введения CORM-2 в костном мозге увеличивалось количество моноцитов, лимфоцитов и плазматических клеток. Полученные результаты указывают, что CORM-2 способен модулировать иммунный ответ.

Ключевые слова: газотрансмиттер, монооксид углерода, CORM-2, иммунный ответ.

Актуальные вопросы фрармацевтической и медицинской науки и практики. 2020. Т. 13, № 3(34). С. 415-420

Among pharmacological drugs, there is a lot that has immunomodulatory properties [1]. These drugs can be divided into 2 groups: immunostimulants and immunosuppressants. The latter is widely used for the treatment of autoimmune diseases after an organ transplant procedure. Some antibiotics also belong to immunosuppressants, cytostatics, and hormonal drugs [1]. All of them cause adverse reactions, which increase with increasing dose. That is why search for drugs that can gently suppress the activity of the immune system and not cause catastrophic changes in other organs and systems of the body remains relevant. One of these applicants is a representative of the gas transmitter group - carbon monoxide (CO) [2,3].

CO is known as poison gas, however, in 1968, Tenhunen et al. reported that this gas is formed in the body during the breakdown of heme. After that, the period of studying the physiological effects of $\mathrm{CO}$ began $[4,5]$. Today, it is known that $\mathrm{CO}$ in a picomolar amount is able to suppress cell apoptosis [6], stimulates $\mathrm{Ca}^{2+}$ dependent $\mathrm{K}$-channels [7], blocks T-cell proliferation [8], and is able to affect mitochondrial activity [9]. 
The only problem with using $\mathrm{CO}$ was that the dosage of this gas is difficult to carry out, poisoning is possible. In this regard, further studies of the therapeutic effects of $\mathrm{CO}$ are inhibited. This problem was solved by creating compounds - donors of CO [10]. After the introduction of such a compound into the body, a slow release of $\mathrm{CO}$ occurs in insignificant, controlled amounts. One of the representatives of these compounds is CORM-2 (tricarbonyldichlororuthenium (II) dimer), which is based on the carbonyl compound of ruthenium. Among several different CORMs synthesized, CORM-2 has been used extensively in vivo studies. CORM2 rapidly liberates $\mathrm{CO}$ in physiological buffers (half-life of about $1 \mathrm{~min}$ at $37^{\circ} \mathrm{C}, \mathrm{pH} \mathrm{7.4)}$. Due to the fact that this compound is not toxic, it is therefore used in experimental studies. Its advantage is that this drug does not affect changes in carboxyhemoglobin levels. CORM-2 serves an important role in CO-mediated pharmacology.

It has been proven that CORM-2 has antioxidant activity in plasma [11], accelerates the healing of gastric ulcers [12], regulates the permeability of the mitochondrial membrane [13], and affects the duration of the cell cycle $[14,15]$. The above confirms the relevance of the study of the $\mathrm{CO}$ donor and the effect of this compound on bone marrow and the production of immunoglobulins under conditions of antigenic stimulation.

\section{Aim}

To reveal the effect of CORM-2 on the level of immunoglobulins in the blood serum and bone marrow of mice under conditions of inducing an immune response.

\section{Materials and research methods}

The study was conducted on white outbred laboratory mice weighing $22 \pm 3$ g. 2 experimental groups of 15 males each were formed. Sheeps red blood cells were intraperitoneally injected into all animals to induce an immune response ("Pharmstandard Biolek", Ukraine) at a dose of 100 cells per $1 \mathrm{~kg}$ of body weight. In the first experimental group, during the inductive phase ( $1^{\text {st }}$ day of immunization), CORM-2 $(20 \mathrm{mg} / \mathrm{kg})$ dissolved in dimethyl sulfoxide (DMSO) and physiological saline was administered. The animals of the experimental group No. 2 were injected with the same solution but during the period of the productive phase ( $5^{\text {th }}$ day after immunization). The control group consisted of 15 male white mice that were also immunized but did not receive CORM-2. The study was conducted on white outbred laboratory mice weighing $22 \pm 3 \mathrm{~g}$. Two experimental groups of 15 males each were formed. Sheeps red blood cells were intraperitoneally administered to all animals to induce an immune response.

To determine the amount of $\operatorname{IgA}$, IgM, and IgG immunoglobulins, an enzyme-linked immunosorbent assay kit ("Granum", Ukraine) was used. Detection of the results of the study was performed using an ELISA analyzer Immunohem-21100, HTI (USA) on the $2^{\text {nd }}$ and $6^{\text {th }}$ day after immunization.

At the end of the experiment ( $6^{\text {th }}$ day), euthanasia was performed by an overdose of isoflurane. Femur bones were isolated and bone marrow imprints were obtained. The obtained imprints were stained with Romanovsky-Giemsa paint and bone marrow cell populations were counted using a microscope.

All procedures with laboratory animals were carried out in compliance with the Council of Europe directives of the EU in 2010/63/EU and were approved by the bioethical commission of Kherson State University. Statistical processing was performed using the Mann-Whitney and Wilcoxon criteria. In this case, the result was considered reliable at $\mathrm{P} \leq 0.05$. The degree of correlation of indicators was calculated using the Pearson correlation coefficient.

\section{Results}

Comparison of serum immunoglobulin levels under conditions of induction an immune response showed differences. In the control group, the level of $\operatorname{IgA}$ increased by $81.0 \pm 4.0 \%$, IgM - by $35.3 \pm 1.8 \%$, and $\operatorname{IgG}$ - by $47.0 \pm 1.9 \%$ (Fig. 1).

The result of the level of immunoglobulins in the serum of animals that were injected with CORM-2 on the first day of the immune response turned out to be interesting. In this group, the content of IgA increased by $100 \pm 5 \%$, IgM remained at the same level, $\mathrm{IgG}$ increased only by $6.8 \pm 0.3 \%$ (Fig. 2).

But, after comparing this group with the control group, it was found that the level of IgA on the next day (after CORM-2 injection) was reduced by $22.0 \pm 1.1 \%(1.09 \mathrm{~g} / \mathrm{L}$ versus $1.41 \mathrm{~g} / \mathrm{L}$ of the control group). On the $6^{\text {th }}$ day, it was reduced by $15.0 \pm 0.75 \%(2.18 \mathrm{~g} / \mathrm{L}$ versus $2.56 \mathrm{~g} / \mathrm{L}$ of the control group).

The IgM level (on the $2^{\text {nd }}$ day) after comparison with the control group was reduced by $12.0 \pm 0.6 \%(1.49 \mathrm{~g} / \mathrm{L}$ versus $1.7 \mathrm{~g} / \mathrm{L}$ of the control). On the $6^{\text {th }}$ day, it was reduced by $35.0 \pm 1.75 \%(1.49 \mathrm{~g} / \mathrm{L}$ versus $2.3 \mathrm{~g} / \mathrm{L}$ of the control group $)$. Similar results were obtained after comparing the $\mathrm{IgG}$ values. Its level was reduced on the $2^{\text {nd }}$ day by $10.5 \pm 0.5 \%(9.32 \mathrm{~g} / \mathrm{L}$ versus $10.42 \mathrm{~g} / \mathrm{L}$ of the control). On the $6^{\text {th }}$ day, the level was also reduced, but already by $35.0 \pm 1.75 \%(9.95 \mathrm{~g} / \mathrm{L}$ versus $15.32 \mathrm{~g} / \mathrm{L}$ of the control group).

The level of immunoglobulins in the serum of the group of mice that were injected with CORM-2 in the productive period of the immune response was radically different from the other two (Fig. 3). The amount of IgA in serum increased by $67.0 \pm 3.3 \%$, while IgM decreased by $48.7 \pm 2.4 \%$, IgG decreased by $17.0 \pm 0.8 \%$.

A study of bone marrow changes showed that the injection of CORM-2 influenced the proliferation of individual cell types after stimulation of the immune response (Fig. 4).

Compared with the control, in the group of animals to which CORM-2 was injected on the first day of the induction of the immune response (group No. 1), the number of myeloblasts decreased by $34.0 \pm 1.7 \%$, myelocytes by $42.5 \pm 1.7 \%$, basophilic normoblasts by $73.0 \pm 3.6 \%$, megakaryocytes - by $76.0 \pm 3.8 \%$. At the same time, there was an increase in the content of the following bone 


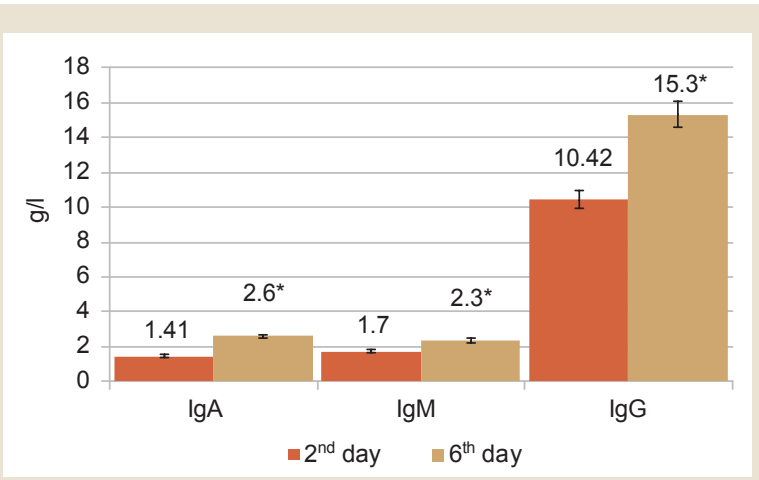

Fig. 1. Level of immunoglobulins in the serum of control group during inductive ( $2^{\text {nd }}$ day) and productive ( $6^{\text {th }}$ day) phases of the immune response.

*: differences from the indicator that were obtained on the $2^{\text {nd }}$ day,

$P \leq 0.5$

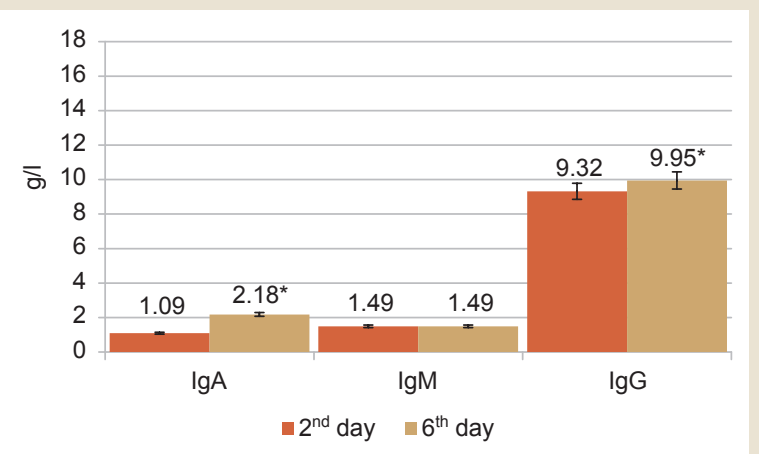

Fig. 2. Level of immunoglobulins in the serum of mice injected with the CORM-2 on the first day.

*: differences from the indicator that were obtained on the $2^{\text {nd }}$ day, $\mathrm{P} \leq 0.05$.

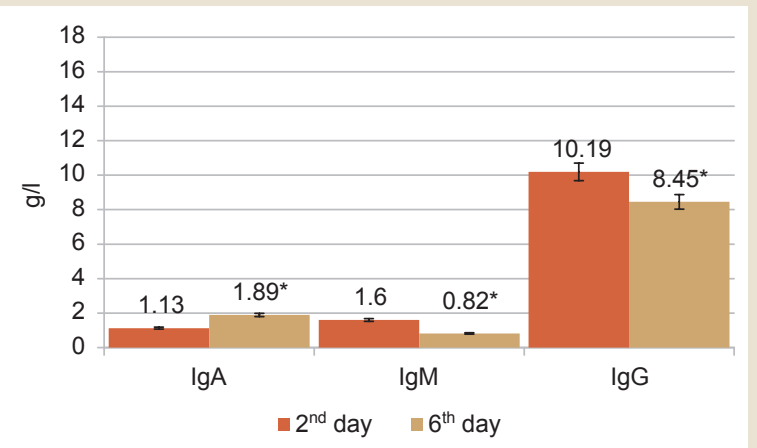

Fig. 3. Level of immunoglobulins in the serum of mice injected with the CORM-2 on the $5^{\text {th }}$ day.

*: differences from the indicator that were obtained on the $2^{\text {nd }}$ day, $P \leq 0.05$

marrow cells: monocytes by $56.0 \pm 2.8 \%$, erythroblasts by $57.0 \pm 2.8 \%$, polychrome normoblasts by $171.0 \pm 8.5 \%$, lymphocytes/lymphoblasts by $56.0 \pm 2.8 \%$, plasma cells by $70.0 \pm 3.5 \%$. Against this background, the content of promyelocytes, metamyelocytes, oxyphilic normoblasts, eosinophils, and basophils did not change.
In the bone marrow of mice that were injected with CORM-2 during the productive period of the immune response (group No. 2), a decrease in myeloblast levels by $25.0 \pm 1.0 \%$, promyelocytes by $52.0 \pm 2.6 \%$, myelocytes by $51.0 \pm 2.4 \%$, and metamyelocytes by $58.0 \pm 3.5 \%$, basophilic normoblasts by $83.0 \pm 4.2 \%$, megakaryocytes - by $99.0 \pm 4.9 \%$ was observed. Moreover, the content of the following cells was increased: neutrophils by $42.0 \pm 2.1 \%$, eosinophils by $178.0 \pm 8.9 \%$, monocytes by $22.0 \pm 1.1 \%$, polychromophilic normoblasts by $146.0 \pm 7.3 \%$, oxyphilic normoblasts by $65.0 \pm 3.2 \%$, lymphocytes/lymphoblasts by $73.0 \pm 3.6 \%$, plasma cells by $35.0 \pm 1.7 \%$. At the same time, the level of basophils and erythroblasts did not change (compared with the control group).

A correlation analysis revealed a direct, close relationship between immunoglobulin counts and a decrease in the population level of certain bone marrow cells. In group No. 1, a close correlation was observed between the level of serum immunoglobulins and the content of polychromic and oxyphilic normoblasts, lymphocytes/lymphoblasts, plasma cells, megakaryocytes.

In group No. 2, the level of immunoglobulins correlates with the levels of myeloblasts, basophilic normoblasts, polychrome, and oxyphilic normoblasts, lymphocytes, and plasma cells.

\section{Discussion}

The results indicate that intraperitoneal injection of CORM-2 directly affects the course of the immune response. CORM-2 inhibits the production of immunoglobulins during the induction phase of the immune response. In comparison with the control, the level of IgA and IgG was reduced, but the amount of IgM did not change. It is known that an increase in serum IgM is characteristic of the primary immune response stage. This indicates that CORM-2 is a promising anti-inflammatory agent. This property of CORM-2 indicates the possibility of its use in autoimmune diseases or to prevent the development of chronic inflammation.

The injection of CORM-2 during the productive phase of the immune response decreased the level of IgM and IgG, however, an increase in the level of IgA was observed at the same time (it is known that $\operatorname{IgA}$ is "responsible" for the so-called local immunity). This property of CORM-2 is promising to use in cases of immunodeficiency, reactions after transfusion measures, or medications that cause selective IgA deficiency.

Injection of CORM-2 during the inductive period of the immune response stimulated (or led to a delay in the bone marrow) separation of monocytes, erythroblasts and normoblasts, as well as lymphoblasts, and plasma cells. This was observed against a background of a decrease in the number of myeloblasts, myelocytes, basophilic normoblasts, and megakaryocytes. Injection of CORM-2 during the productive period also showed a decrease in the number of myeloblasts, promyelocytes, myelocytes, metamyelocytes, basophilic 


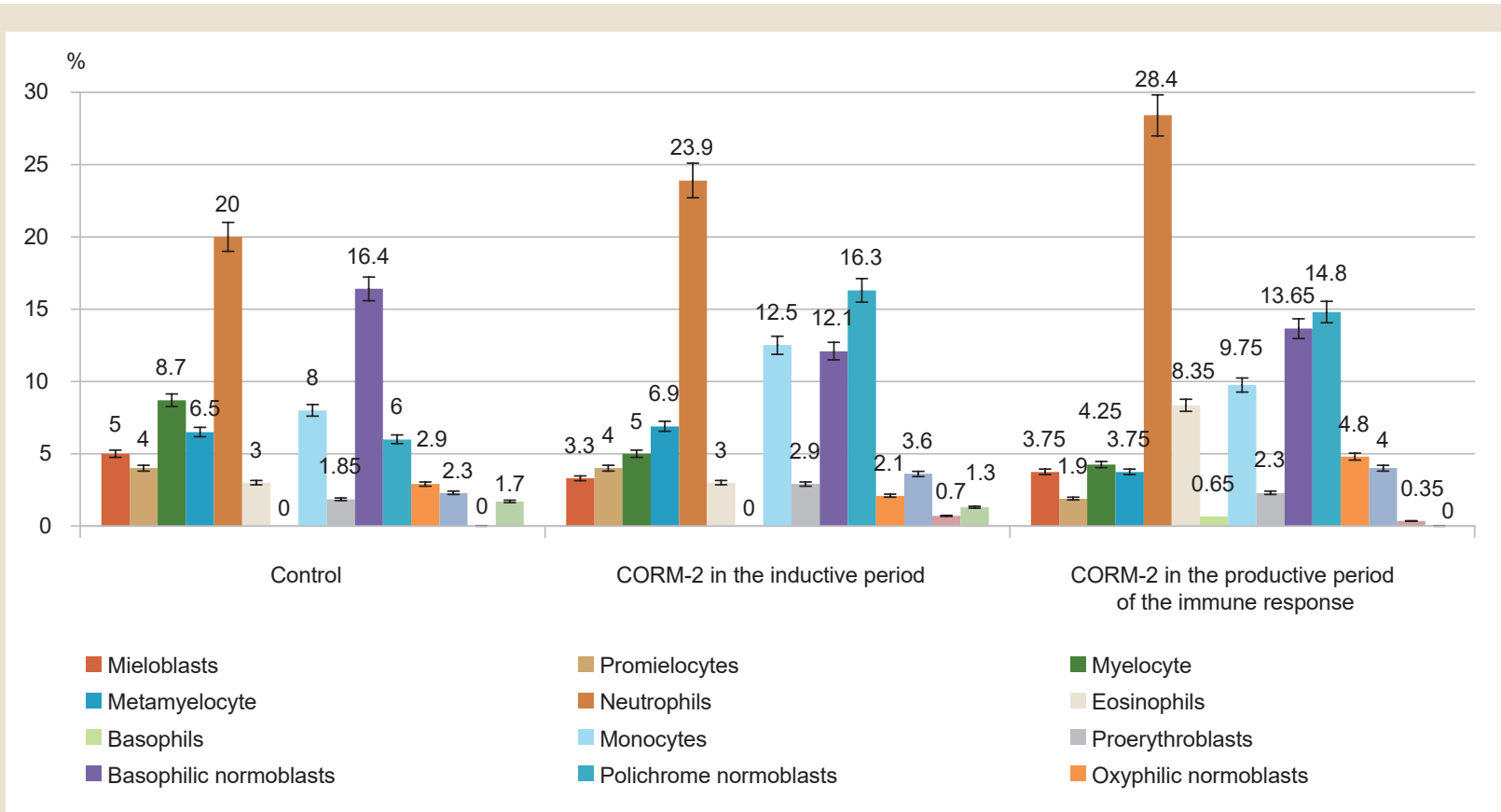

Fig. 4. Content of red bone marrow cells in the studied animals.

normoblasts, and megakaryocytes. At the same time, the level of neutrophils, eosinophils, monocytes, polychromophilic and oxyphilic normoblasts, lymphocytes and plasma cells increased. Thus, it was found that CORM-2 stimulates an increase in the number of monocytes, lymphocytes, and plasma cells, regardless of the stage of the immune response.

After the action of $\mathrm{CO}$, which is released from CORM-2, inducible heme oxygenase (HO-1) is activated. It should be noted that inhalation of $\mathrm{CO}$ does not increase the activity of HO-1 [14]. Its activity is enhanced only by CORM-2, which once again confirms that CORMs are suitable for these purposes.

Thus, the release of $\mathrm{CO}$ leads to the activation of the HMOX1 gene. Activation of this gene increases HO-1 activity. HO-1 is known to be a metabolite to fight inflammation. The anti-inflammatory ability of HO-1 is realized by increasing the expression of interleukin 10 (IL-10) and an antagonist of the pro-inflammatory interleukin 1 receptor (IL-1RA) [9].

After we stimulated the immune response and introduced anti-inflammatory CORM-2, HO-1, likely, affects the cells of the immune system, bone marrow stem cells. This mechanism may explain the findings of the study.

\section{Conclusions}

1. The injection of CORM-2 during the induction phase of the immune response enhances the production of IgA and IgG. The amount of IgM remained at the same level. An increase in the number of monocytes, erythroblasts, and normoblasts, as well as lymphoblasts and plasma cells, was observed in the bone marrow. At the same time, there was a decrease in the number of myeloblasts, myelocytes, basophilic normoblasts, and megakaryocytes.
2. During the productive phase of the immune response, CORM-2 lowered the level of IgM and IgG with a simultaneous increase in IgA level. The number of neutrophils, eosinophils, monocytes, polychromophilic and oxyphilic normoblasts, lymphocytes, and plasma cells in the bone marrow increased. However, there was a decrease in the number of myeloblasts, promyelocytes, myelocytes, metamyelocytes, basophilic normoblasts, and megakaryocytes.

Prospects for further research. In the future, a study of the properties of CORM-2 regarding the processes of tissue regeneration and healing will be conducted in vivo.

\section{Funding}

The research was performed within the research work of Kherson State University "Effects of certain vasoactive substances on central and peripheral lymphatic organs of white mice" state registration number $0117 \mathrm{U} 001764$.

Conflicts of interest: authors have no conflict of interest to declare. Конфрлікт інтересів: відсутній.

Information about authors:

Beschasnyi S. P., PhD, Associate Professor of the Department of Human Biology and Immunology, Kherson State University, Ukraine.

ORCID ID: 0000-0002-7423-4112

Hasiuk O. M., PhD, Associate Professor, Head of the Department of Human Biology and Immunology, Kherson State University, Ukraine. ORCID ID: 0000-0003-1055-2848

Відомості про авторів:

Бесчасний С. П., канд. біол. наук, доцент каф. біології людини та імунології, Херсонський державний університет, Україна. Гасюк О. М., канд. біол. наук, доцент, зав. каф. біології людини та імунології, Херсонський державний університет, Україна. 
Сведения об авторах:

Бесчасный С. П., канд. биол. наук, доцент каф. биологии человека и иммунологии, Херсонский государственный университет, Украина. Гасюк Е. Н., канд. биол. наук, доцент, зав. каф. биологии человека и иммунологии, Херсонский государственный университет, Украина.

\section{References}

[1] Gladka, I. V., \& Shkuropat, A. V. (2016). Efektyvnist khimichnykh ta biolohichnykh metodiv preventsii rozvytku bakterioziv plodiv Capsicum anuum [Effectiveness of chemical and biological methods of prevention of bacteriosis Capsicum anuum]. Pryrodnychyi almanakh. Seria: Biolohichni nauky, (23), 13-19. [in Ukrainian]. http://na.kspu. edu/index.php/na/article/view/462

[2] Fayad-Kobeissi, S., Ratovonantenaina, J., Dabiré, H., Wilson, J. L., Rodriguez, A. M., Berdeaux, A., Dubois-Randé, J., Mann, B., Motterlini, R., \& Foresti, R. (2016). Vascular and angiogenic activities of CORM-401, an oxidant-sensitive CO-releasing molecule. Biochemical Pharmacology, 102, 64-77. https://doi.org/10.1016/j.bcp.2015.12.014

[3] Ji, X., Damera, K., Zheng, Y., Yu, B., Otterbein, L. E., \& Wang, B. (2016). Toward Carbon Monoxide-Based Therapeutics: Critical Drug Delivery and Developability Issues. Journal of pharmaceutical sciences, 105(2), 406-416. https://doi.org/10.1016/i.xphs.2015.10.018

[4] Kolupaev, Yu. E., Karpets, Yu. V., Beschasniy, S. P., \& Dmitriev, A. P. (2019). Gasotransmitters and their role in adaptive reactions of plant cells. Cytology and Genetics. 53, 392-406. https://doi. org/10.3103/S0095452719050098

[5] Rose, J. J., Wang, L., Xu, Q., McTiernan, C. F., Shiva, S., Tejero, J., \& Gladwin, M. T. (2017). Carbon Monoxide Poisoning: Pathogenesis, Management, and Future Directions of Therapy. American journal of respiratory and critical care medicine, 195(5), 596-606. https://doi. org/10.1164/rccm.201606-1275Cl

[6] Olas, B. (2014). Carbon monoxide is not always a poison gas for human organism: Physiological and pharmacological features of $\mathrm{CO}$. Chemico-biological interactions, 222, 37-43. https://doi.org/10.1016/i. cbi.2014.08.005
[7] Beschasnyi, S., \& Hasiuk, O. (2020). CO-Releasing Molecule (CORM-2) in the Regulation of $\mathrm{Ca}^{2+}$-Dependent $\mathrm{K}^{+}$-Permeability of Erythrocyte. Ukrainian Journal of Medicine, Biology and Sport, 5(2), 166-171. https://doi.org/10.26693/imbs05.02.166

[8] Park, J., Joe, Y., Ryter, S. W., Surh, Y. J., \& Chung, H. T. (2019). Similarities and Distinctions in the Effects of Metformin and Carbon Monoxide in Immunometabolism. Molecules and cells, 42(4), 292-300. https://doi.org/10.14348/molcells.2019.0016

[9] Motterlini, R., \& Foresti, R. (2017). Biological signaling by carbon monoxide and carbon monoxide-releasing molecules. American journal of physiology. Cell physiology, 312(3), C302-C313. https:// doi.org/10.1152/ajpcell.00360.2016

[10] Ryter, S. W., \& Choi, A. M. (2016). Targeting heme oxygenase-1 and carbon monoxide for therapeutic modulation of inflammation. Translational research : the journal of laboratory and clinical medicine, 167(1), 7-34. https://doi.org/10.1016/j.trsl.2015.06.011

[11] Adach, W., \& Olas, B. (2017). The role of CORM-2 as a modulator of oxidative stress and hemostatic parameters of human plasma in vitro. PloS one, 12(9), e0184787. https://doi.org/10.1371/journal.pone.0184787

[12] Magierowski, M., Magierowska, K. Hubalewska-Mazgaj, M., Sliwowski, Z., Ginter, G., Pajdo, R., Chmura, A., Kwiecien, S., \& Brzozowski, T. (2017). Carbon monoxide released from its pharmacological donor, tricarbonyldichlororuthenium (II) dimer, accelerates the healing of pre-existing gastric ulcers. British journal of pharmacology, 174(20), 3654-3668. https://doi.org/10.1111/bph.13968

[13] Tashireva, L. A., Starikova, E. G., Novickij, V. V., \& Rjazanceva, N. V. (2012). Vnutrikletochnye misheni proapoptoticheskogo vlijanija gazovyh transmitterov [Intracellular targets of proapoptotic influence of gaseous transmitters]. Annals of the Russian academy of medical sciences, 67(10), 77-81. [in Russian]. https://doi.org/10.15690/vramn.v67i10.420

[14] Starikova, Ye. G. (2012). Antiproliferativnyi potentsial monooksida ugleroda [Antiproliferative potential of carbon monoxide]. Bulletin of Siberian Medicine, 11(4), 68-71. [in Russian]. https://doi. org/10.20538/1682-0363-2012-4-68-71

[15] Mahan V. L. (2020). Cardiac function dependence on carbon monoxide. Medical gas research, 10(1), 37-46. https://doi.org/10.4103/20459912.279982 